\title{
Poly-Dianix Blue/Multi-Walled Carbon Nanotube Modified Electrode for Detection of Levodopa in the Presence of High Concentrations of Ascorbic and Uric Acids
}

\author{
Abdolhamid Hatefi-Mehrjardi, ${ }^{1,2, *}$ Mohammad Ali Karimi, ${ }^{1}$ Azam Barani ${ }^{2}$ \\ and Mahdiyeh Soleymanzadeh ${ }^{2}$ \\ ${ }^{1}$ Department of Chemistry, Payame Noor University, 19395-3697, Tehran, Iran \\ ${ }^{2}$ Department of Chemistry \& Nanoscience and Nanotechnology Research Laboratory (NNRL), \\ Payame Noor University (PNU), Sirjan, Iran \\ * Corresponding author: E-mail: hhatefy@pnu.ac.ir or hhatefy@ Yahoo.com \\ Tel: +98-34-423-335-41; Fax: +98-34-423-335-40
}

Received: 24-11-2016

\begin{abstract}
A selective and sensitive electrochemical sensor was studied for determination of levodopa (LD) in the presence of uric acid (UA) and ascorbic acid (AA) using poly-dianix blue and multi-walled carbon nanotubes (PDB/MWCNTs) modified glassy carbon electrode. Cyclic voltammetry, differential pulse voltammetry, and chronoamperometry methods were applied to investigate the electrocatalytic oxidation of LD, UA and AA in aqueous solutions. By DPV technique, LD, UA and AA give oxidation peaks at $0.380,0.520$ and $0.180 \mathrm{~V}$, respectively. Under the optimized experimental conditions LD, UA and AA give a linear response in the range of 0.09-75 $\mu \mathrm{mol} \mathrm{L}^{-1}, 0.3-110 \mu \mathrm{mol} \mathrm{L}{ }^{-1}$ and $10-160 \mu \mathrm{mol} \mathrm{L}^{-1}$, respectively. Accordingly, the obtained detection limits were $0.003,0.002$ and $0.023 \mu \mathrm{mol} \mathrm{L}^{-1}$. The method provides a simple electrochemical sensor for successful determination of LD in human blood serum samples.
\end{abstract}

Keywords: Dianix Blue; Carbon Nanotubes; Modified Electrode; Levodopa; Uric Acid; Ascorbic Acid.

\section{Introduction}

Parkinson's disease (PD) is a progressive neurologic disorder that leads to a slowly increasing asthenia in movement. It is caused by a lack of dopamine, a natural substance usually found in the brain. Dopamine cannot be administered directly because it does not cross the bloodbrain barrier easily. Levodopa (LD) is one of central nervous system drugs and passes into the brain and is then converted to dopamine by decarboxylase. Then, LD is utilized to increase dopamine levels in the brain. ${ }^{1}$ Clearly, the process of LD detection and its concentration determination is an important property in pharmaceutical and clinical procedures. Different analytical methods have been developed in order to measure LD levels in various sample matrices, such as spectrophotometric, ${ }^{2}$ high-performance liquid chromatography, ${ }^{3}$ and capillary zone elec- trophoresis. ${ }^{4,5}$ All these methods involve complicated techniques and expensive instruments. Compared to other choices, electrochemical methods provide useful alternatives that are faster, cheaper and highly sensitive. ${ }^{6-10}$

Ascorbic acid (AA) is commonly known as vitaminC. ${ }^{11}$ AA plays an important role in several enzymatic reactions and in the defense against oxidative stress. ${ }^{12}$ According to these properties, it is utilized for the prevention and treatment of infertility, Alzheimer's disease, atherosclerosis, cancer ${ }^{13,14}$ and AIDS. ${ }^{15,16}$ However, at higher concentration levels, AA contributes to the formation of kidney stones.

Uric acid (UA) is a nitrogenous compound and the primary major product of purine catabolism. ${ }^{17}$ Continuous monitoring of UA in the body fluid is vital since its abnormal concentration levels result in different diseases, such as hyperuricaemia and gout. ${ }^{18}$ Several methods for the de- 
tection of UA have been explained in papers including enzymatic-spectrophotometry ${ }^{19}$ and chemiluminescence. ${ }^{20}$ However, most of these methods are complicated because they need derivatization of compound with variety detection methods. Therefore, it is favorable to have a simple, sensitive and fast method for monitoring the concentration of UA in biological fluids such as electrochemical techniques. ${ }^{21,22}$

Whereas LD, UA and AA play the main role in the human body and often coexist in biological fluids, the selective detection of these three compounds has always been the subject of many types of research. ${ }^{15}$ As LD, UA and AA are all electroactive, electrochemical methods are often utilized to the determination of these three species. ${ }^{23,24}$ However, the direct redox reactions of these species at the bare electrodes take place at very similar potentials ${ }^{25-28}$ and often suffer from a pronounced fouling effect, which results in a poor selectivity and reproducibility. ${ }^{29,30}$ Also, the voltammetric sensing of neurotransmitter metabolites usually suffers from the interference of AA, which usually coexists in vivo as anion at high concentrations and possesses an oxidation potential close to that of neurotransmitter metabolites at the unmodified electrode ${ }^{31}$ Moreover, one promising approach for minimizing overvoltage effects and facilitating the determination is through the use of an electrocatalytic process at chemically modified electrodes. The most commonly used electrode material is carbon particularly glassy carbon $(\mathrm{GC}),{ }^{32}$ accordingly the chemical modifications of the inert substrate of glassy carbon electrode with redox active thin films offer significant advantages in the design and development of electrochemical sensors. ${ }^{33}$ Modification of GC electrodes can be achieved by numerous ways, and the electropolymerization method has been widely explored. ${ }^{34}$ Compared with the conventionally adsorbed layer, the electropolymerized conductive sensing film is more uniform and the thickness is easily controlled by controlling the number of potential sweep cycles. More importantly, the polymeric sensing films on the electrode surface can yield a three-dimensional reaction zone which can provide more active sites for anodic oxidation of LD, UA and AA and greatly increase the sensitivity of the resulting sensor. ${ }^{35}$

Carbon nanotubes (CNTs) are considered to be good supports for polymer-modified GC electrodes, because of their good electric conductivity, small dimensions, high mechanical strength, ${ }^{36}$ electric ${ }^{37,38}$ and thermal behavior, ${ }^{39,40}$ and the property of being polymer carriers. ${ }^{41,42}$

In the previous work, the poly-(Alizarin Red S)-modified glassy carbon electrode was successfully fabricated and used for the electrochemical detection of LD, homovanillic acid, and $\mathrm{AA}$ in the presence of the each other. ${ }^{43}$ However, modification with new nanocomposite materials offers advanced properties.

In this study, PDB/MWCNTs-modified GC electrode was electrochemically prepared and used as an elec- trochemical sensor for determination of LD, UA and AA in the presence of the each other. The results have been compared with the bare GCE and PDB/GCE based on electrocatalytic oxidation, and some parameters influencing the performances of this electrode in the determination of the three species are discussed. In fact, the redox active sites shuttle electrons between the analytes and the electrode shows a significant reduction in activation overpotentials.

\section{Experimental}

\section{1. Chemicals and Solutions}

LD, UA and AA were obtained from Alfa Aesar, Fluka (Switzerland) and Merck (Germany), respectively. Dianix blue (4,8-diamino-1,5-dihydroxy-2-(4-hydroxyphenyl)-4a,9a-dihydroanthracene-9,10-dione) with the molecular mass of $362.34 \mathrm{~g} \mathrm{~mol}^{-1}$, the structural formula of $\mathrm{C}_{20} \mathrm{H}_{14} \mathrm{~N}_{2} \mathrm{O}_{5}$ and the following molecular formula (Scheme 1) was purchased from Dy Star.

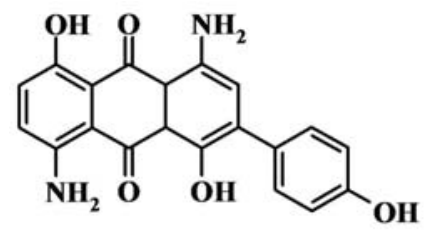

Scheme 1. The structural formula of Dianix blue.

MWCNTs with purity more than $95 \%$ were purchased from Research Institute of Petroleum Industry (Iran). MWCNT purification was performed as given in the literature: ${ }^{44} 0.150 \mathrm{~g}$ of MWCNTs were stirred in 12 $\mathrm{mL}$ of concentrated $\mathrm{HNO}_{3} / \mathrm{H}_{2} \mathrm{SO}_{4}$ mixture $3: 1$ for $24 \mathrm{~h}$. The solid product was filtered using a membrane filter with a pore size of $0.2 \mathrm{~m}$, washed with double distilled water until neutral $\mathrm{pH}$ was reached. The filtrate was dried at $80{ }^{\circ} \mathrm{C}$ in an oven for $24 \mathrm{~h}$. Other reagents were of analytical grade purchased from Merck and used without further purification. Electrolyte solutions were prepared using Smalley method. ${ }^{45}$ The initial $\mathrm{pH}$ of the solution $0.10 \mathrm{~mol} \mathrm{~L}^{-1} \mathrm{KCl}+0.01 \mathrm{~mol} \mathrm{~L}^{-1} \mathrm{H}_{3} \mathrm{PO}_{4}$ was $c a$. 2.1. The higher $\mathrm{pHs}$ were adjusted by the addition of $0.11 \mathrm{~mol} \mathrm{~L}^{-1} \mathrm{NaOH}$. Ionic strength was constant over the entire range of $\mathrm{pH}$. All electrochemical experiments were carried out in $0.11 \mathrm{~mol} \mathrm{~L}^{-1} \mathrm{PBS}$ at $\mathrm{pH}$ 3.0. Freshly prepared LD, UA and AA solutions were used for each experiment. All aqueous solutions were made with double-distilled water.

\section{2. Apparatus}

A conventional cell with three electrodes including bare GCE or modified GCE with PDB or PDB/MWCNTs 
as working electrode, $\mathrm{Ag} / \mathrm{AgCl}\left(3.0 \mathrm{~mol} \mathrm{~L}^{-1} \mathrm{KCl}, \mathrm{Me}-\right.$ trohm) as reference electrode and platinum bar (Metrohm) as auxiliary electrode, was employed for electrochemical experiments. The cyclic voltammetry and differential pulse voltammetry and chronoamperometry experiments were carried out using an Autolab P/GSTAT 12 (Eco Chemie, The Netherlands) interfaced with a computer and controlled by GPES 4.9 software. The topological imaging of the electrodes was performed by AFM using Nanosurf Easy Scan 2 AFM (Nanosurf AG, Switzerland) and Field Emission Scanning Electron Microscope (FESEM, MIRA, TESCAN, USA). AFM images were taken in the air in the contact/tapping mode and were obtained at least in three different sites in given samples.

\section{3. Electrode Modification}

Before electrode modification, the GCE (nominal area of $0.0314 \mathrm{~cm}^{2}$, Azar electrode Co., Urmia, Iran) was polished using aqueous slurries of alumina $(0.05 \mu \mathrm{m})$ on polishing cloth. Then it was rinsed with double-distilled water, and sonicated in water/ethanol/water each for 3 min respectively. The suspension of DB/MWCNTs was prepared from at least $2 \mathrm{~h}$ ultra-sonication of DB $(0.1$ mmol L ${ }^{-1}$ ) and MWCNTs (1 wt\% DB) in PBS. ${ }^{46}$ The cleaned electrode was immersed in the suspension of DB/MWCNTs and conditioned out by cyclic potential sweeping between -0.2 to $+1.8 \mathrm{~V}$ at $0.100 \mathrm{~V} \mathrm{~s}^{-1}$ for 40 scans. After electropolymerization, the modified electrode was rinsed with distilled water and utilized for electrochemical measurements.

\section{Results and Discussion}

\section{1. Fabrication and Characterization of PDB/MWCNTs Modified GCE}

The non-conducting polymer films devoted to developing sensors and biosensors have a very thin thickness $(10-100 \mathrm{~nm})$ due to their self-limited growing. ${ }^{47}$ The nonconducting films also have favorable perm-selective properties which could be used to reduce possible electrochemical interferences in samples. Therefore, fast response time and high selectivity could also be expected for nonconducting polymers modified GCE. Based on non-covalent interactions such as $\pi-\pi$ stacking, van der Waals interaction and strong adsorption, they interact with MWCNTs, increasing the solubility of MWCNT in water and therefore stabilizing the DB/MWCNTs solution. Cyclic voltammetry was used to form electro-polymerized film and the redox behavior of DB in the presence of MWCNTs was investigated between -0.2 and $1.8 \mathrm{~V}$ at the clean glassy carbon electrode. The consecutive cyclic voltammograms (the first 10 cycles) are plotted in Figure 1. As the number of cycles increases, the anodic currents in-

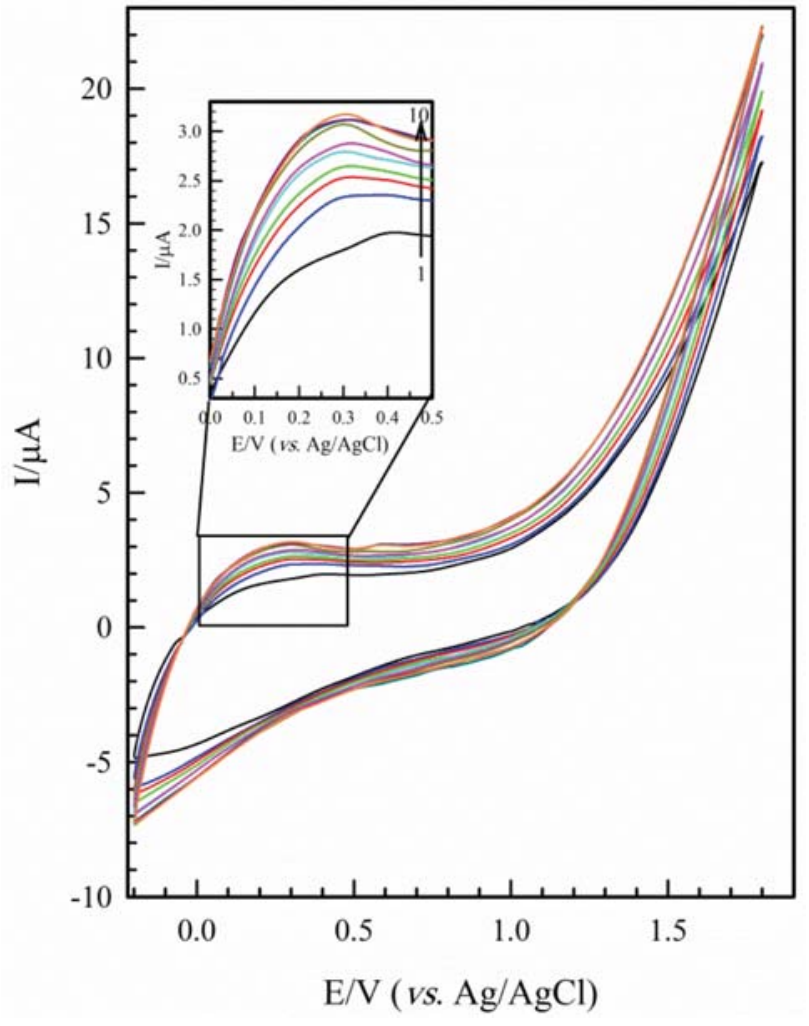

Figure 1. Successive cyclic voltammograms of GCE in $0.11 \mathrm{M}$ PBS (pH 3) containing the suspension of DB/MWCNTs for first 10 cycles. The scan rate was $0.100 \mathrm{~V} \mathrm{~s}^{-1}$.

crease until a steady state after about 7 cycles. It is an evidence that a polymeric product with the anthraquinone basis formed on the electrode surface.

The morphological characteristics of the modified electrodes were studied by SEM and AFM. Fig. 2 represents the topography SEM and AFM images acquired from the surface of bare GC, PDB/GC and PDB/MWCNT-GC electrodes.

The SEM images of smooth and homogeneous surface correspond to the unmodified (a) and modified GCE with PDB (b). While the PDB/MWCNTs modified GCE (c) reveal different patterns, this obviously shows that the electrode surface is covered electrochemically by PDB/MWCNTs in three dimensions. The AFM images indicate that the modified electrode surface with $\mathrm{PDB} / \mathrm{MWCNTs}$ film is throughout rough and in comparison to $\mathrm{PDB} / \mathrm{GC}$ and bare GC electrode, increases its microscopic area significantly and the resulting currents in voltammetric measurements.

\section{2. Electrochemical Behavior of LD, UA and $\mathrm{AA}$ in a Mixture at Modified GCE}

In order to study the selectivity of the PDB/MWCNTs-GCE, the cyclic voltammograms of LD, $\mathrm{UA}$ and $\mathrm{AA}$ in PBS, $\mathrm{pH} 3$, were recorded at the bare and 


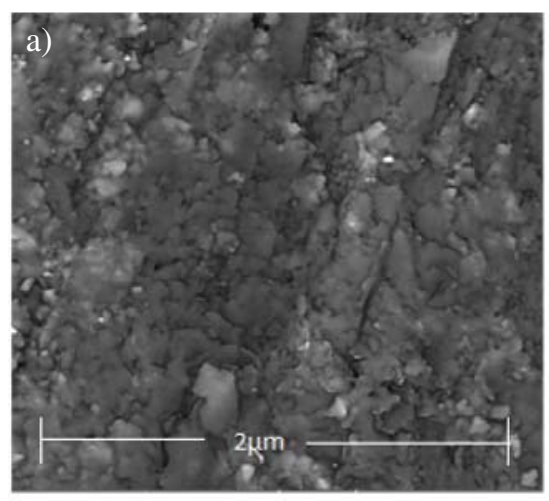

Topography - Scan forward
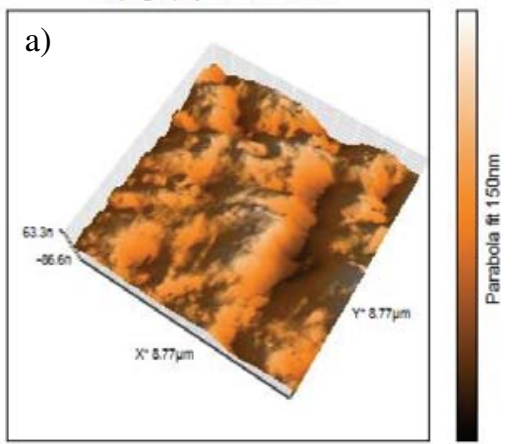

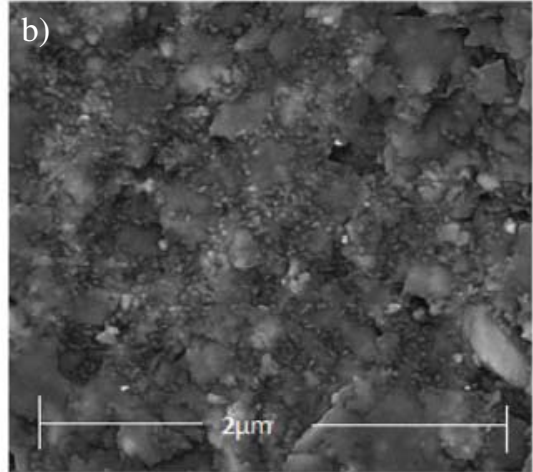

Topography - Scan forward

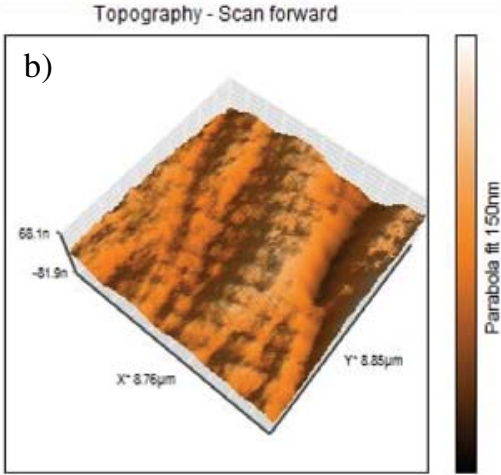

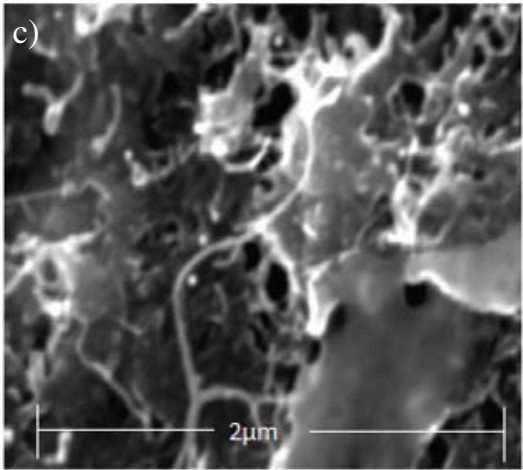

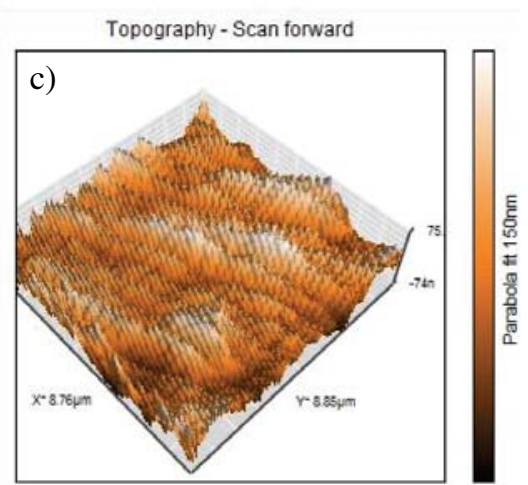

Figure 2. SEM (top) and AFM (down) images of bare GC (a), PDB/GC (b) and PDB/MWCNTs-GC (c) electrodes
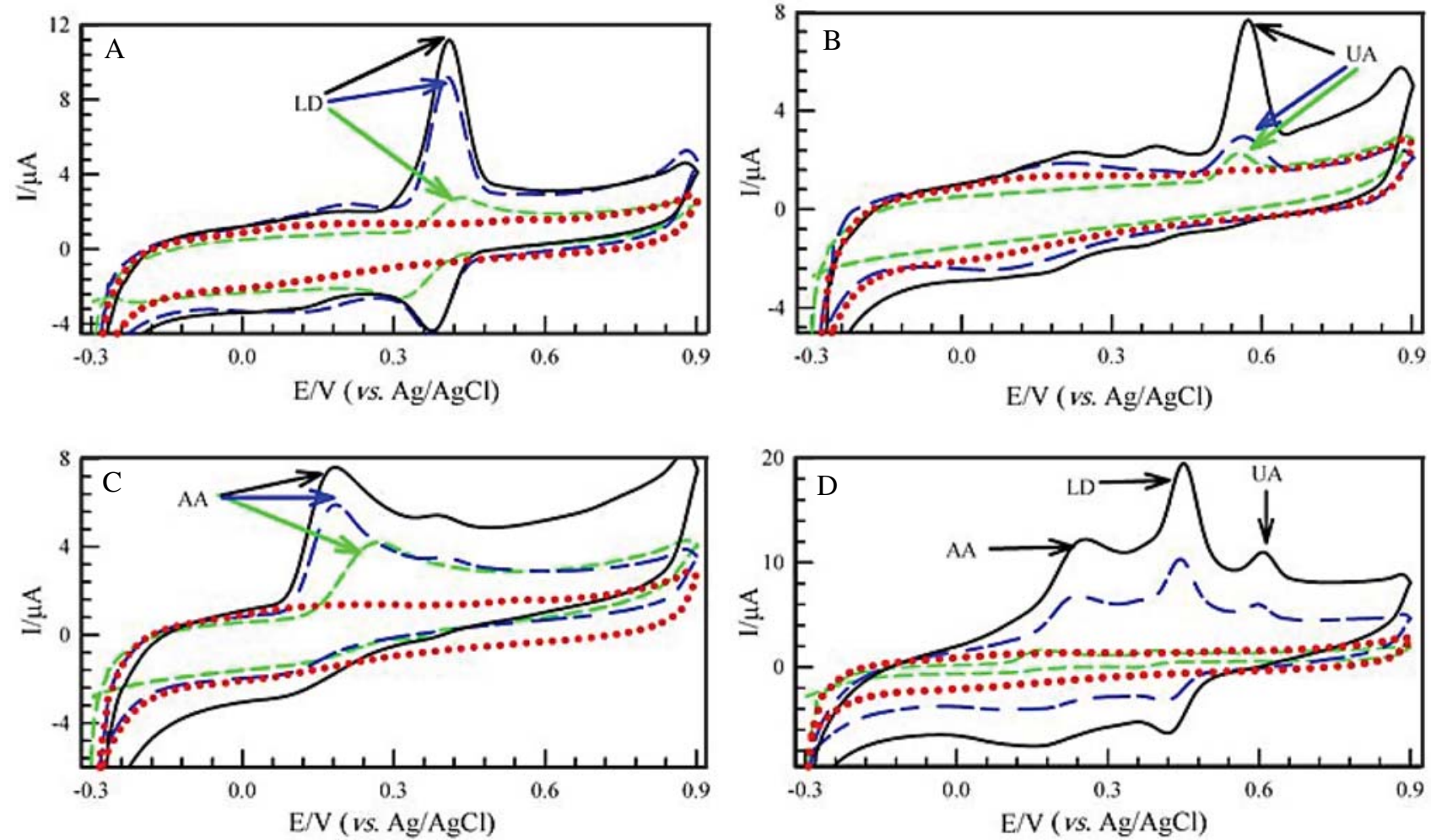

Figure 3. Cyclic voltammograms of blank solution in the absence of any analyte (red dotted lines) and $2 \mu \mathrm{mol} \mathrm{L} \mathrm{L}^{-1} \mathrm{LD}(\mathrm{A}), 60 \mu \mathrm{mol} \mathrm{L} \mathrm{L}^{-1} \mathrm{UA}(\mathrm{B})$, $100 \mu \mathrm{mol} \mathrm{L}{ }^{-1} \mathrm{AA}(\mathrm{C})$ and the mixture of the three analytes (D) obtained on the surface of bare GC (green short dashed lines), modified PDB/GC (blue long dashed lines), and PDB/MWCNTs-GC electrodes (solid black lines). The potential scan rate was $0.100 \mathrm{~V} \mathrm{~s}^{-1}$ and supporting electrolyte was $0.11 \mathrm{~mol} \mathrm{~L}^{-1} \mathrm{PBS}, \mathrm{pH} 3.0$. 
modified electrodes (Fig. 3). It can be shown that the anodic peak potentials for the LD (A), UA (B), and AA (C) oxidation at the bare GC electrode are about $0.432,0.554$, and $0.268 \mathrm{~V}$, respectively, whereas the respective potentials at the surface of the PDB/MWCNTs modified GC electrode are about $0.411,0.573$, and $0.182 \mathrm{~V}$.

Fig. 3 (D) shows cyclic voltammograms for a mixture of $2 \mu \mathrm{mol} \mathrm{L}^{-1}, 60 \mu \mathrm{mol} \mathrm{L}{ }^{-1}$ and $100 \mu \mathrm{mol} \mathrm{L}^{-1}$ of LD, UA and $\mathrm{AA}$, respectively in $0.11 \mathrm{~mol} \mathrm{~L}^{-1} \mathrm{PBS}$ solution $(\mathrm{pH}$ 3.0) at bare GCE, PDB/GCE and PDB/MWCNTs-GCE. As can be seen, at bare GCE the oxidation peaks for LD, UA and AA are overlapped together with low currents and this shows slow electron transfer kinetics. At the PDB/MWCNTs modified GCE, three well-defined oxidation peaks appear at $0.450,0.607$ and $0.255 \mathrm{~V}$ for $\mathrm{LD}$, UA and AA, respectively. The oxidation responses of $\mathrm{LD}, \mathrm{UA}$ and AA show a great enhancement in the peak currents at PDB/MWCNTs-GCE in comparison with PDB-GCE and bare GCE. Also, when we compare the oxidation peak potentials of LD, UA and AA, there is an enhancement of the anodic peak separation at the PDB/MWCNTs-GCE relative to the values specified at the PDB/GCE and bare GCE. So, the LD, UA and AA peaks potential separations are large enough for the determination of these compounds in the presence of each other at PDB/MWCNTs-GCE. The enhancement in the LD, UA and AA oxidation peak current is mainly attributed to the considerable increment in the electroactive area of the electrode due to the presence of MWCNTs. This phenomenon makes possible the determination of all of these compounds with satisfactory separation between their oxidation peak potentials in voltammetry.

\section{3. Effect of $\mathrm{pH}$ on the Oxidation of LD}

In order to find the optimum $\mathrm{pH}$ for determination of $\mathrm{LD}$, the effect of supporting electrolyte $\mathrm{pH}$ was studied. In this case, cyclic voltammetry studies were carried out in the $\mathrm{pH}$ range of $2.0-9.0\left(\mathrm{PBS}, 0.11 \mathrm{~mol} \mathrm{~L}^{-1}\right.$ ) at the surface of PDB/MWCNTs-GCE. Fig. 4 shows cyclic voltammograms obtained for oxidation of $\mathrm{LD}$ at the surface of PDB/MWCNTs-GCE at different $\mathrm{pH}$ values. The maximum peak current can be observed at $\mathrm{pH}$ 3.0. In addition, all the peak potentials for the oxidation of LD shifted towards negative direction with increasing $\mathrm{pH}$. Therefore, $\mathrm{pH} 3.0$ was selected for further experiments. According to the linear plots of $\mathrm{E}_{\mathrm{p}, \mathrm{a}}$ vs. $\mathrm{pH}$ concerning the observed slope of $-0.057 \mathrm{~V} / \mathrm{pH}$ for LD (above of the Fig. 4), which is very close to the expected Nernstian value of $0.059 \mathrm{~V}$ at $25{ }^{\circ} \mathrm{C}$, where np (number of protons) $=$ ne (number of electrons).

\section{4. Chronoamperometry Studies}

The catalytic electro-oxidation of LD at the surface of the PDB/MWCNTs-GCE was studied by short time

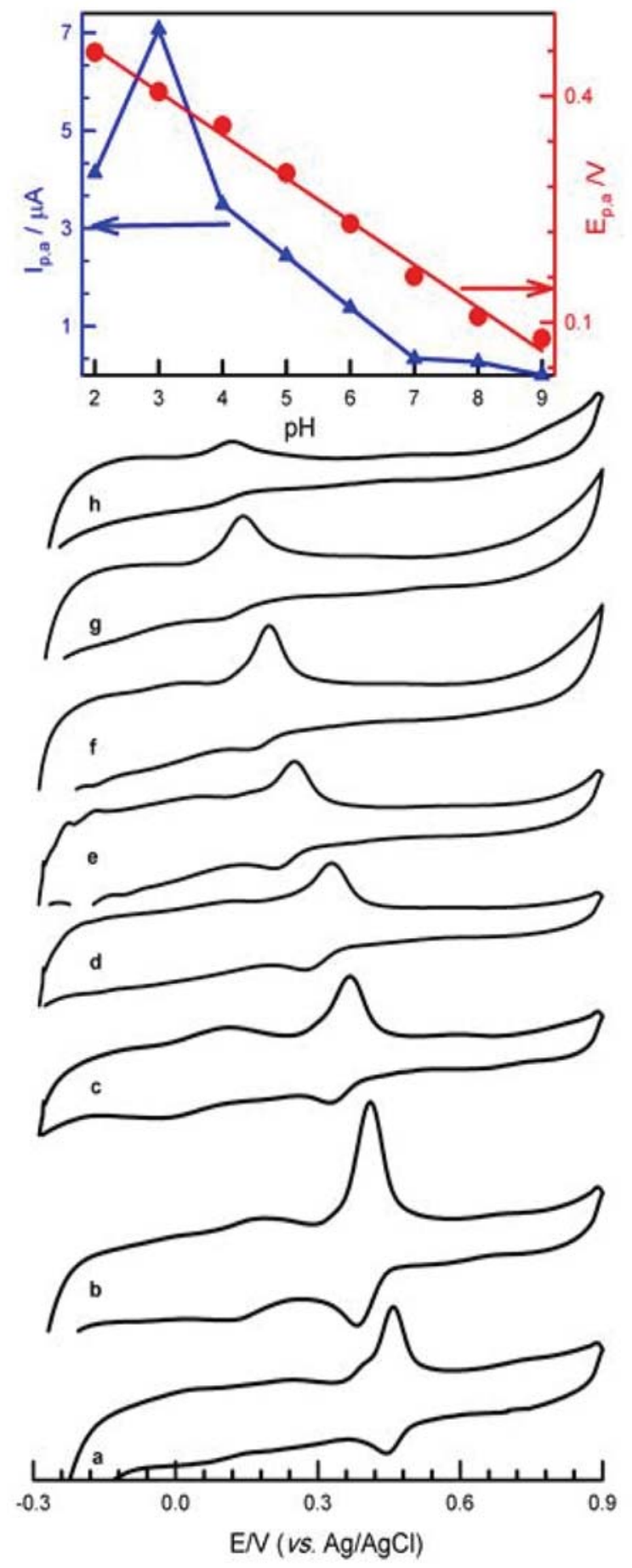

Figure 4. Cyclic voltammograms of $60 \mu \mathrm{M} L D$ at the PDB/MWCNTs-GCE in $0.11 \mathrm{~mol} \mathrm{~L}^{-1} \mathrm{PBS}$ at $\mathrm{pH}$ (a) 2.0, (b) 3.0, (c) 4.0 , (d) 5.0 , (e) 6.0 , (f) 7.0, (g) 8.0 and (h) 9.0. The scan rate is $0.100 \mathrm{~V} \mathrm{~s}^{-1}$. Also, the plots of the extracted $\mathrm{I}_{\mathrm{p}, \mathrm{a}}$ and $\mathrm{E}^{0}, v s$. $\mathrm{pH}$ are shown above.

chronoamperometry technique. Fig. 5A indicates the chronoamperograms of the different concentrations of LD in PBS (pH 3.0) obtained on PDB/MWCNTs-GC modified electrode by setting the working electrode potentials to $0.5 \mathrm{~V} v s$. $\mathrm{Ag} / \mathrm{AgCl}\left(\mathrm{KCl} 3 \mathrm{~mol} \mathrm{~L}^{-1}\right)$. 


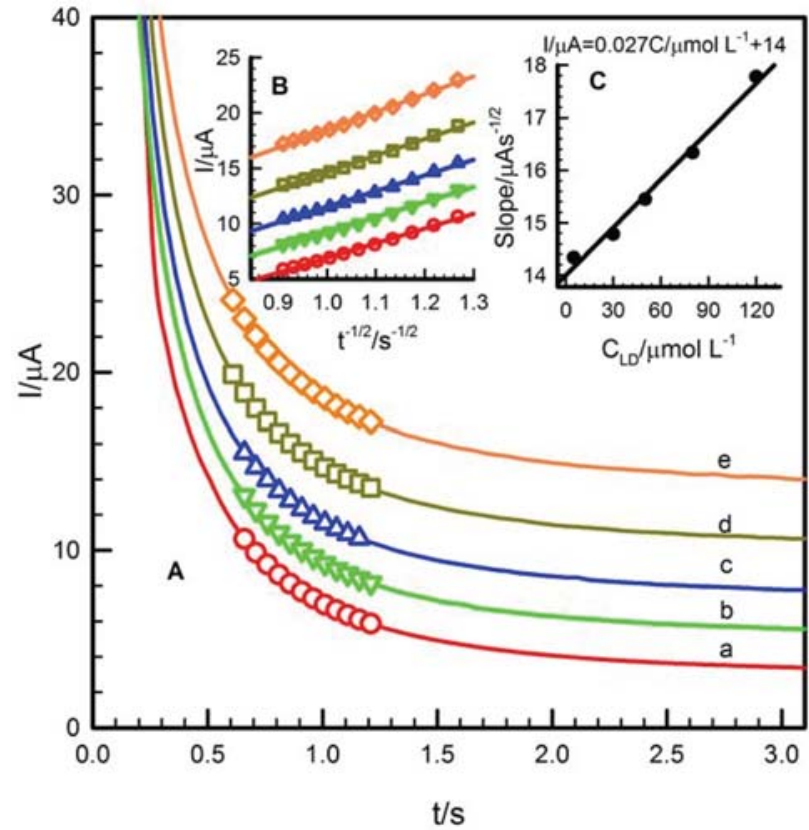

Figure 5. Chronoamperograms of (a) 5.0; (b) 30.0; (c) 50.0; (d) 80.0 ; (e) $120.0 \mu \mathrm{mol} \mathrm{L}^{-1}$ of LD in PBS $\left(0.11 \mathrm{~mol} \mathrm{~L}^{-1}\right.$, pH 3.0) obtained on PDB/MWCNTs-GCE, at the initial potential of $0.0 \mathrm{~V}$ and step potential of $0.5 \mathrm{~V} v$ s. $\mathrm{Ag} / \mathrm{AgCl}\left(\mathrm{KCl} 3 \mathrm{~mol} \mathrm{~L}^{-1}\right)(\mathrm{A})$. The inset shows $\mathrm{I}$ as a function of $\mathrm{t}^{-1 / 2}(\mathrm{~B})$. The inset shows the slope of lines $\mathrm{B}$ as a function of the concentrations of $\mathrm{LD}(\mathrm{C})$.

The diffusion coefficient (D) for oxidation of LD at the surface of the modified electrode can be evaluated using Cottrell's equation:

$$
\mathrm{I}=\mathrm{nFAD}^{1 / 2} \mathrm{C}_{\mathrm{b}} \pi^{-1 / 2} \mathrm{t}^{-1 / 2}
$$

Where $\mathrm{D}$ and $\mathrm{C}_{\mathrm{b}}$ are the diffusion coefficient $\left(\mathrm{cm}^{2}\right.$ $\mathrm{s}^{-1}$ ) and the bulk concentration $\left(\mathrm{mol} \mathrm{cm}{ }^{-3}\right)$, respectively. Under diffusion control conditions, the plots of selected currents versus $\mathrm{t}^{-1 / 2}$ would be linear. The value of $\mathrm{D}$ could be evaluated from the slope of these plots, according to the Cottrell equation. Fig. 5B indicates the experimental plots for different concentrations of LD in the range of $5-120 \mu \mathrm{mol} \mathrm{L}{ }^{-1}$. The mean value of the diffusion coefficients for LD was calculated to be $6.23 \times 10^{-5} \mathrm{~cm}^{2} \mathrm{~s}^{-1}$ using the slopes of the resulting straight lines plotted versus the LD concentrations (Fig. 5C).

\section{5. Differential Pulse Voltammetric Determination of $\mathrm{LD}, \mathrm{UA}$ and $\mathrm{AA}$}

Since differential pulse voltammetry (DPV) has a much higher current sensitivity and better resolution than cyclic voltammetry, it was applied for study of LD, UA and AA concentration at PDB/MWCNTs-GCE. Under the optimized solution conditions $\left(0.11 \mathrm{~mol} \mathrm{~L}^{-1} \mathrm{PBS}, \mathrm{pH} 3\right)$, the DPVs of various concentrations of LD, UA and AA were separately recorded (Fig. 6). The respective calibration curves of the anodic peak currents for solutions containing different amounts of each analyte were plotted

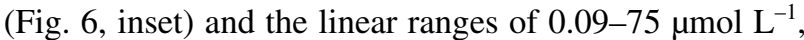
$0.3-110 \mu \mathrm{mol} \mathrm{L}{ }^{-1}$ and $10-160 \mu \mathrm{mol} \mathrm{L}{ }^{-1}$ were obtained for LD, UA, and AA, respectively.

The limits of detection $(3 \sigma)$ for determination of LD, UA, and AA on the modified electrode surface, were found to be 3,2 , and $23 \mathrm{nmol} \mathrm{L}^{-1}$, respectively. Also, the modified electrode presented good repeatability. The rela-

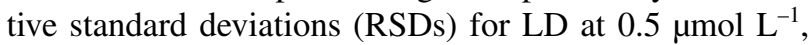
$\mathrm{UA}$ at $3 \mu \mathrm{mol} \mathrm{L} \mathrm{L}^{-1}$, and AA at $15 \mu \mathrm{mol} \mathrm{L}{ }^{-1}$ were $0.25 \%$, $0.61 \%$, and $2.1 \%$, respectively, for 6 measurements which reveal that the sensor had good repeatability.

\section{6. Simultaneous Determination of LD, UA and AA in the Mixture}

The ability of the PDB/MWCNTs modified GC electrode for simultaneous determination of each analyte was
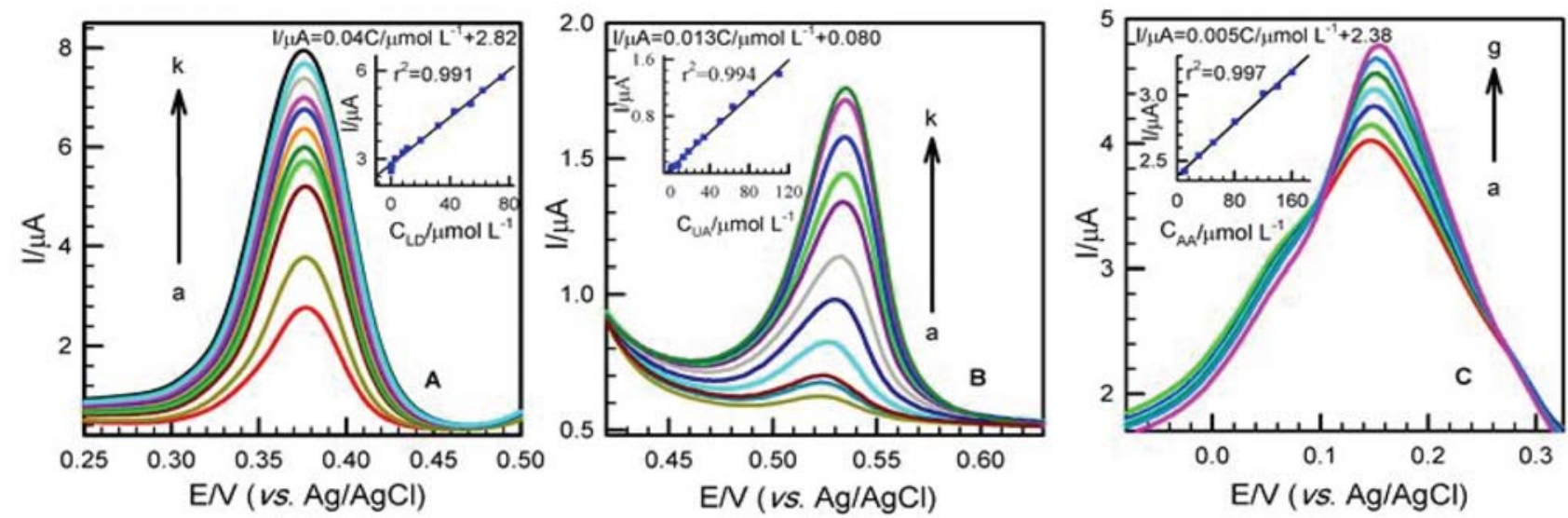

Figure 6. Differential pulse voltammograms of LD (A), UA (B), and AA (C) at PDB/MWCNTs-GCE in $0.11 \mathrm{~mol} \mathrm{~L}^{-1}$ PBS (pH 3). LD concentra-

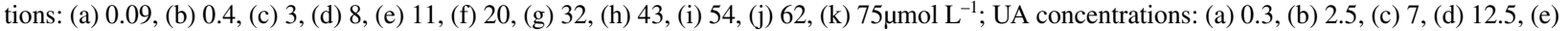
18, (f) 26.5, (g) 33.5, (h) 50, (i) 63, (j) 82, (k) $110 \mu \mathrm{mol} \mathrm{L}-1$ and AA concentrations: (a) 10, (b) 30, (c) 50, (d) 80, (e) 120 , (f) 140 , (g) $160 \mu \mathrm{mol} \mathrm{L}{ }^{-1}$. Insets show the calibration lines from the DPVs shown in (A), (B) and (C). 
examined by addition of various concentrations of the species in the presence of the constant concentration of the others (Fig. 7). Under the optimal conditions, by increasing of various concentrations of LD, UA and AA, three separated peaks appeared at the potential of about $0.380,0.520$ and $0.180 \mathrm{~V}$, respectively. By increasing the concentration of LD in the presence of $50 \mu \mathrm{mol} \mathrm{L}{ }^{-1} \mathrm{UA}$ and $200 \mu \mathrm{mol} \mathrm{L}$ AA (Fig. 7A), the peak current of LD increased linearly with increasing $\mathrm{LD}$ concentration in the range of $0.8-72$ $\mu \mathrm{mol} \mathrm{L}^{-1}$ and the related regression calibration is $\mathrm{I} / \mu \mathrm{A}=$ $0.10 \mathrm{C} / \mu \mathrm{mol} \mathrm{L} \mathrm{L}^{-1}+0.58$ (Fig. 7A, inset). It is observable that the oxidation peaks related to UA and AA are approximately constant. Furthermore, different concentrations of UA in the presence of $1.7 \mu \mathrm{mol} \mathrm{L}^{-1} \mathrm{LD}$ and $220 \mu \mathrm{mol} \mathrm{L}^{-1} \mathrm{AA}$ illustrate excellent DPVs responses (Fig. 7B); the peak current of UA grows linearly by increasing UA concentration in the range of $0.3-110 \mu \mathrm{mol} \mathrm{L} \mathrm{L}^{-1}$ and the related regression calibration is $\mathrm{I} / \mu \mathrm{A}=0.008 \mathrm{C} / \mu \mathrm{mol} \mathrm{L} \mathrm{L}^{-1}+0.11$ (Fig. $7 \mathrm{~B}$, inset) which shows simultaneous determination of UA in the presence of LD and AA on the surface of PDB/MWCNTsmodified GCE. We also observed oxidation peaks of various amounts of AA in the presence of a constant concentration of LD $\left(2 \mu \mathrm{mol} \mathrm{L}^{-1}\right)$ and UA $\left(20 \mu \mathrm{mol} \mathrm{L}^{-1}\right)$ (Fig. 7C). There is no serious variation observed in the peak current of LD and UA, but the peak current of AA in the concentration range of 1-160 $\mu \mathrm{mol} \mathrm{L}^{-1}$ increased linearly with calibration regression equation of $\mathrm{I} / \mu \mathrm{A}=0.013 \mathrm{C} / \mu \mathrm{mol} \mathrm{L} \mathrm{L}^{-1}+1.0$ (Fig. $7 \mathrm{C}$, inset). These results indicate that the electrochemical determination of three analytes in the presence of each other on the PDB/MWCNTs- modified GCE surface is possible independently.

\section{7. Interference Studies}

Under the optimal experimental conditions, the influence of various interfering species on the determination of $5.5 \mu \mathrm{mol} \mathrm{L} \mathrm{L}^{-1} \mathrm{LD}$ was investigated. The tolerance limit was taken as the maximum concentration of the foreign compound which caused an approximately $\pm 5 \%$ relative error in the determination of the analyte. The experimental results show that neither 500 -fold excess concentration of $\mathrm{Ni}^{2+}, \mathrm{Fe}^{3+}, \mathrm{Cu}^{2+}, \mathrm{Co}^{2+}, \mathrm{Mn}^{2+}, \mathrm{Na}^{+}, \mathrm{K}^{+}, \mathrm{Mg}^{2+}, \mathrm{Ca}^{2+}, \mathrm{Al}^{3+}$, $\mathrm{Pb}^{2+}, \mathrm{Cl}^{-}, \mathrm{NO}_{3}^{-}, \mathrm{SO}_{4}^{2-}, \mathrm{PO}_{4}^{3-}, \mathrm{CO}_{3}{ }^{2-}, \mathrm{HCO}_{3}{ }^{-}$nor 300 -fold excess of glucose, lactose, sucrose, fructose, glycine, L-lysine, and riboflavin did not interfere, but practically equal molar concentrations of dopamine, DOPAC, homovanillic acid, epinephrine, and norepinephrine showed interference on determination of LD.

\section{8. Real Samples Analysis}

In order to evaluate the analytical applicability of the proposed sensor, direct determination of LD, UA and AA were applied for two physiological samples (human blood serum). The human blood plasma samples were collected from clinical laboratory and diluted 4 times by 0.11 mol L ${ }^{-1}$ PBS solution ( $\mathrm{pH} 3$ ) without any treatment. The recoveries of these three analytes in blood serum were determined by the standard addition method (Table 1) and satisfactory results were obtained.

These results show that the PDB/MWCNTs-GC modified electrode is an excellent sensitive tool for simultaneous determination of the analytes in physiological samples.

\section{Conclusions}

In the present work, it was shown that polyDB/MWCNTs film on the GCE can be considered as a sensitive and selective sensing element in the simultaneous voltammetric determination of LD, UA and AA. The
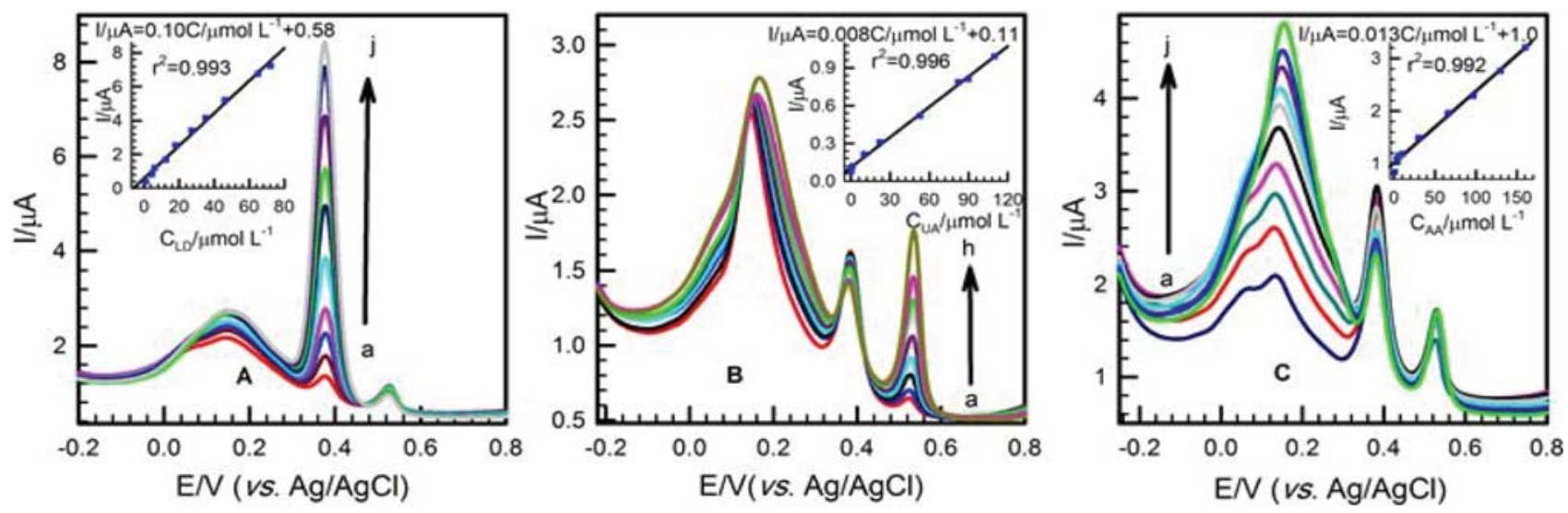

Figure 7. Differential pulse voltammograms of PDB/MWCNTs-GCE in PBS $0.11 \mathrm{~mol} \mathrm{~L}^{-1}$ (pH 3), containing (A) LD concentrations: (a) 0.8 , (b)

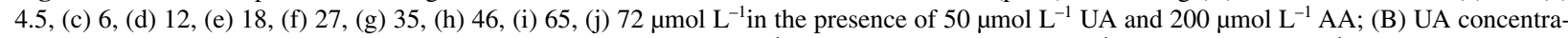
tions: (a) 0.3 , (b) 1 , (c) 10 , (d) 22 , (e) 53, (f) 82 , (g) 90 , (h) $110 \mu \mathrm{mol} \mathrm{L}^{-1}$ in the presence of $1.7 \mu \mathrm{mol} \mathrm{L} \mathrm{L}^{-1} \mathrm{LD}$ and $220 \mu \mathrm{mol} \mathrm{L} \mathrm{L}^{-1} \mathrm{AA}$; (C) AA concen-

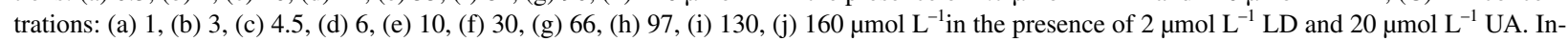
sets: The related calibration plots from the DPVs are shown in (A), (B) and (C). 
Table 1. Determination and recovery tests of LD, UA and AA in real samples obtained using PDB/MWCNTs-GC modified electrode.

\begin{tabular}{|c|c|c|c|c|}
\hline Analyte & Sample & $\operatorname{Added}\left(\mu \mathrm{mol} \mathrm{L}{ }^{-1}\right)$ & Found $\left(\mu \mathrm{mol} \mathrm{L}{ }^{-1}\right)$ & Recovery $(\%)$ \\
\hline \multirow[t]{8}{*}{$\overline{\mathrm{LD}}$} & Serum 1 & 0 & 0.112 & - \\
\hline & & 10 & 9.909 & 98.00 \\
\hline & Serum 2 & 0 & 0.130 & - \\
\hline & & 16 & 16.21 & 100.5 \\
\hline & Serum $1^{a}$ & 0 & 0.154 & - \\
\hline & & 10 & 10.50 & 103.5 \\
\hline & Serum $2^{a}$ & 0 & 0.093 & - \\
\hline & & 4 & 3.958 & 96.70 \\
\hline \multirow[t]{4}{*}{ AA } & Serum 1 & 0 & 0.297 & - \\
\hline & & 25 & 24.60 & 97.26 \\
\hline & Serum 2 & 0 & 0.221 & - \\
\hline & & 20 & 20.62 & 102 \\
\hline \multirow[t]{4}{*}{ UA } & Serum 1 & 0 & 0.168 & - \\
\hline & & 20 & 20.00 & 99.20 \\
\hline & Serum 2 & 0 & 0.087 & - \\
\hline & & 10 & 10.52 & 104.3 \\
\hline
\end{tabular}

a. The recovery tests of $\mathrm{LD}$ were performed in the presence of $35 \mu \mathrm{mol} \mathrm{L}-1$ AA and $12 \mu \mathrm{mol} \mathrm{L}{ }^{-1} \mathrm{UA}$ in real samples

modified electrode showed an effective electrocatalytic activity toward the anodic oxidation of LD, UA and AA, which leads to a significant increase in the peak currents and a decrease in peak over-potentials. The good resolution was observed between the DPV peak potentials of $\mathrm{LD}$, UA and AA, showing this is a very appropriate method for the voltammetric determination of the compounds. This method is financially more reasonable than chromatographic separation methods. Furthermore, sensor production is easy and fast, and there is no need to use complex pretreatment or toxic organic synthetic materials. In other words, they belong to green chemistry.

\section{Acknowledgements}

The authors gratefully acknowledge the Payame Noor University providing research facilities for this work.

\section{References}

1. W. J. Weiner, Parkinson's disease: diagnosis and clinical management, Medical Publishing, New York, 2002.

2. T. Madrakian, M. Mohammadnejad, Chem. Pharm. Bull. 2007, 55, 865-670. https://doi.org/10.1248/cpb.55.865

3. S. F. Li, H. L. Wu, Y. J. Yu, Y. N. Li, J. F. Nie, H. Y. Fu, R. Q. Yu, Talanta 2010, 81, 805-.812

4. S. Zhao, W. Bai, B. Wang, M. He, Talanta 2007, 73, 142146. https://doi.org/10.1016/j.talanta.2007.03.023

5. V. Ladero, N. Martínez, M. C. Martín, M. Fernández, M. A. Alvarez, Food Res. Int. 2010, 43, 289-295. https://doi.org/10.1016/j.foodres.2009.10.007

6. M. S. M. Quintino, M. Yamashita, L. Angnes, Electroanalysis 2006, 18, 655-661. https://doi.org/10.1002/elan.200503445

7. C. Zapata-Urzúa, M. Pérez-Ortiz, M. Bravo, A. C. Olivieri, A. Álvarez-Lueje, Talanta 2010, 82, 962-968. https://doi.org/10.1016/j.talanta.2010.05.071

8. P. Daneshgar, P. Norouzi, M. R. Ganjali, A. Ordikhani-Seyedlar, H. Eshraghi, Colloids Surf. B 2009, 68, 27-32. https://doi.org/10.1016/j.colsurfb.2008.09.019

9. S. Shahrokhian, E. Asadian, J. Electroanal. Chem. 2009, 636, 40-46. https://doi.org/10.1016/j.jelechem.2009.09.010

10. H. Beitollahi, J. B. Raoof, R. Hosseinzadeh, Electroanalysis 2011, 23, 1934-1940. https://doi.org/10.1002/elan.201100242

11. E. Luque-Perez, A. Rios, M. Valcarcel, Fresenius J .Anal. Chem. 2000, 366, 857-862. https://doi.org/10.1007/s002160051585

12. S. J. Padayatty, A. Katz, Y. H. Wang, P. Eck, O. Kwon, J. H. Lee, S. L. Chen, C. Corpe, A. Dutta, S. K. Dutta, M. Levine, J. Am. Coll. Nutr. 2003, 22, 18-35. https://doi.org/10.1080/07315724.2003.10719272

13. O. Arrigoni, C. D. Tullio, Biochim. Biophys. Acta. 2002, 1569, 1-9. https://doi.org/10.1016/S0304-4165(01)00235-5

14. S. Sen, R. Chakraborty, The role of antioxidants in human health, in: S. Andreescu, M. Hepel (Eds.), Oxidative Stress: Diagnostics, Prevention, and Therapy, ACS Symposium Series, Washington, 2011, Chap. 1, p.1. https://doi.org/10.1021/bk-2011-1083.ch001

15. A. A. Ensafi, M. Taei, T. khayamian, J. Electroanal. Chem. 2009, 633, 212-220. https://doi.org/10.1016/j.jelechem.2009.06.001

16. S. Shahrokhian, E. Asadin, Electrochim. Acta 2010, 55, 666-672. https://doi.org/10.1016/j.electacta.2009.08.065 
17. E. Popa, Y. Kubota, D. A. Tryk, A. Fujishima, Anal. Chem. 2000, 72, 1724-1727. https://doi.org/10.1021/ac990862m

18. K. Shi, K. K. Shiu, Electroanalysis 2001, 13, 1319-1325. h t t p s : / / d o i.org / 10 . 1002 / 15521 4109(200111)13:16<1319::AID-ELAN1319>3.0.CO;2-C

19. A. K. Bhargava, H. Lal, C. S. Pundir, J. Biochem. Biophys. Methods 1999, 39, 125-192. https://doi.org/10.1016/S0165-022X(99)00007-X

20. D. Yao, A. G. Vlessidis, N. P. Evmriridis, Anal. Chim. Acta 2002, 467, 133-144. https://doi.org/10.1016/S0003-2670(02)00127-7

21. J. X. Qiao, H. Q. Luo, N. B. Li, Colloid Surf. B, 2008, 62, 31-35. https://doi.org/10.1016/j.colsurfb.2007.09.012

22. P. Kalimuthu, D. Suresh, S. A. John, Anal. Biochem. 2006, 357, 188-193. https://doi.org/10.1016/j.ab.2006.07.031

23. X. Yang, J. Kirsch, A. Simonian, J. Microbiol. Methods 2013, 95, 48-56. https://doi.org/10.1016/j.mimet.2013.06.023

24. X. Yang, J. Kirsch, E. V. Olsen, J.W. Fergus, A.L. Simonian, Sens. Actuators B 2013, 177, 659-667. https://doi.org/10.1016/j.snb.2012.11.057

25. W. Cai, T. Lai, H. Du, J. Ye, Sens. Actuators B 2014, 193, 492-500. https://doi.org/10.1016/j.snb.2013.12.004

26. J. B. Raoof, R. Ojani, M. Baghayeri, Anal. Methods 2011, 3, 2367-2373. https://doi.org/10.1039/c1ay05305a

27. L. M. Niu, K. Q. Lian, H. M. Shi, Y. B. Wu, W. J. Kang, S. Y. Bi, Sens. Actuators B 2013, 178, 10-18. https://doi.org/10.1016/j.snb.2012.12.015

28. M. Ahn, J. Kim, J. Electroanal. Chem. 2012, 683, 75-79. https://doi.org/10.1016/j.jelechem.2012.08.012

29. H. R. Zare, N. Rajabzadeh, N. Nasirizadeh, M. MazloumArdakani, J. Electroanal. Chem. 2006, 589, 60-69. https://doi.org/10.1016/j.jelechem.2006.01.011

30. R. M. Wightman, L. J. May, A. C. Michael, Anal. Chem. 1988, 60, 769A-793A. https://doi.org/10.1021/ac00164a718

31. T. Selvaraju, R. Ramaraj, Electrochim. Acta 2007, 52, 29983005. https://doi.org/10.1016/j.electacta.2006.09.032

32. R. L. Mc Creery, Chem. Rev. 2008, 108, 2646-2687. https://doi.org/10.1021/cr068076m
33. M. Mazloum-Ardakani, P. Ebrahimi-Karami, H. Naemi, B. Mirjalili, Turk. J. Chem., 2008, 32, 571-584.

34. H. R. Zare, N.N. Nasirizadeh, and M. Mazloum-Ardakani, $J$. Electroanal. Chem.2005, 577, 25-33. https://doi.org/10.1016/j.jelechem.2004.11.010

35. X. Chen, F. Wang, Z. Chen, Anal. Chim. Acta 2008, 623, 213-220. https://doi.org/10.1016/j.aca.2008.06.021

36. A. B. Dalton, S. Collins, E. Munoz, J. M. Razal, V. H. Ebron, J. P. Ferraris, J. N. Coleman, B. G. Kim, R. H. Baughman, Nature 2003, 423, 703-703. https://doi.org/10.1038/423703a

37. B. E. Kilbride, J. N. Coleman, P. Fournet, M. Cadek, A. Drury, W. J. Blau, J. Appl. Phys. 2002, 92, 4024-4030. https://doi.org/10.1063/1.1506397

38. J. K. W. Sandler, J. E. Kirk, I. A. Kinloch, M. S. P. Shaffer, A. H. Windle, Polymer 2003, 44, 5893-5899. https://doi.org/10.1016/S0032-3861(03)00539-1

49. M. J. Biercuk, M. C. Llaguno, M. Radosavljevic, J. K. Hyun, J. E. Fischer, A. T. Johnson, Appl. Phys. Lett. 2002, 80, 2767-2769. https://doi.org/10.1063/1.1469696

44. C. Wei, K. Srivastava, K. Cho, Nano Lett. 2002, 2, 647-650. https://doi.org/10.1021/n1025554+

41. M. J. Sims, Q. Li, R. T. Kachoosangi, G. G. Wildgoose, R. G. Compton, Electrochim. Acta 2009, 54, 5030-5034. https://doi.org/10.1016/j.electacta.2008.10.056

42. R. T. Kachoosangi, G. G. Wildgoose, R. G. Compton, Anal. Chim. Acta 2008, 618, 54-60. https://doi.org/10.1016/j.aca.2008.04.053

43 . A. Hatefi-Mehrjardi, N. Ghaemi, M.A. Karimi, M. Ghasemi, S. Islami-Ramchahi, Electroanalysis 2014, 26, 24912500. https://doi.org/10.1002/elan.201400302

44. V. Pifferi, G. Cappelletti, C. D. Bari, D. Meroni, F. Spadavecchia, L. Falciola, Electrochim. Acta 2014, 146, 403-410. https://doi.org/10.1016/j.electacta.2014.09.099

45 J. F. Smalley, K. Chalfant, S. W. Feldberg, T. M. Nahir, E. F. Bowden, J. Phys. Chem. B 1999, 103, 1676-1685. https://doi.org/10.1021/jp983325z

46. X-L. Xie, Y-W. Mai, X-P. Zhou, Mater. Sci. Eng. R 2005, 49 , 89-112. https://doi.org/10.1016/j.mser.2005.04.002

47. M. Yuqing, C. Jianrong, W. Xiaohua, Trends Biotechnol. 2004, 22, 227-231. https://doi.org/10.1016/j.tibtech.2004.03.004

\section{Povzetek}

Preučevali smo selektiven in občutljiv elektrokemijski senzor na osnovi s poli-dianiks modrim in večstenskimi ogljikovimi nanocevkami (PDB/MWCNT) modificirano elektrodo iz steklastega ogljika za določanje levodope (LD) v prisotnosti sečne kisline (UA) in askorbinske kisline (AA). Za raziskave elektrokatalitske oksidacije LD, UA in AA v vodnih raztopinah smo uporabili metode ciklične voltametrije, diferencialne pulzne voltametrije in kronoamperometrije. Pri tehniki DPV so LD, UA in AA dali oksidacijske vrhove pri $0,380 \mathrm{~V}, 0,520 \mathrm{~V}$ in $0,180 \mathrm{~V}$. Pri optimiziranih eksperimentalnih pogojih je bil linearen odgovor za LD v območju $0,09-75 \mu \mathrm{mol} \mathrm{L} \mathrm{L}^{-1}$, za UA $0,3-110 \mu \mathrm{mol} \mathrm{L} \mathrm{L}^{-1}$ in za AA v območju $10-160 \mu \mathrm{mol} \mathrm{L}^{-1}$. V skladu s tem so bile meje zaznave $0,003,0,002$ in $0,023 \mu \mathrm{mol} \mathrm{L}{ }^{-1}$. Metoda predstavlja preprost elektrokemijski senzor za uspešno določitev LD v serumskih vzorcih iz humane krvi. 